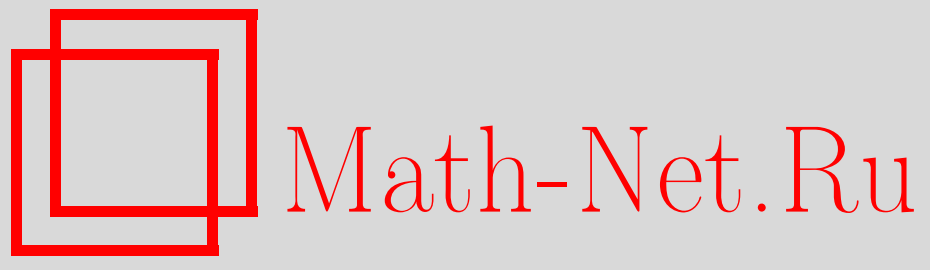

Л. Белопухов, ИТЭР - земная звезда, Квант, 2018, номер 8, 2-11

DOI: https://doi.org/10.4213/kvant20180801

Использование Общероссийского математического портала Math-Net.Ru подразумевает, что вы прочитали и согласны с пользовательским соглашением http://www.mathnet.ru/rus/agreement

Параметры загрузки:

IP: 54.210 .77 .194

26 апреля 2023 г., 17:09:09

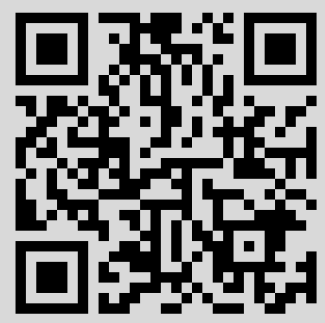




\section{ИТЭР - земная звезда}

\section{Л.БЕЛОПУХОВ}

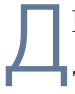
ВАДЦАТЬ ДЕВЯТОГО ЯНВАРЯ 2007 ГОда был дан старт гигантской стройке двадцать первого века - проекту ИТЭР. Международная аббревиатура ITER pacшифровывается как International Thermonuclear Experimental Reactor. Pycское название проекта - международный термоядерный экспериментальный реактор. Возможно, этот день войдет в историю как начало новой энергетической эры человечества, эры термоядерной энергии энергии звезд.

\section{Термоядерная реакция}

Существование нашего мира определяют гравитация и термоядерный синтез. Гравитация создает сгустки водорода и других элементов, которые все более и более уплотняются и разогреваются. Когда температура в центре сгустка достигает $10^{7} \mathrm{~K}$, а давление становится $10^{11}$ Па, вспыхивает ядерная реакция синтеза - превращение водорода в гелий. Температура еще больше повышается, и давление расширяющихся продуктов реакции уравновешивает гравитационное давление. Устанавливается равновесие - образуется звезда. Температура ее центральной части - сотни миллионов градусов, а на поверхности тысячи или десятки тысяч градусов. Энергию реакции синтеза в своих глубинах звезда излучает в пространство. Это и есть ее свечение - инфракрасное, видимое, ультрафиолетовое и рентгеновское.

Если около звезды существуют планеты, то есть вероятность того, что на планетах сможет возникнуть и будет развиваться жизнь. Для этого, кроме излучения звезды, сама планета должна иметь подходящий химический состав веществ на поверхности и такую температуру, чтобы вода находилась в жидком состоянии.

DOI: https://doi.org/10.4213/kvant20180801
В середине прошлого века изучение энергетики ядерных реакций шло двумя путями. Один путь - исследование процессов деления тяжелых ядер, прежде всего изотопов урана. Этот путь дал человечеству атомную бомбу и атомные электростанции (во всем мире, кроме России, их уже довольно давно называют не атомными, а ядерными, что правильнее с научных позиций). Практически одновременно стал ясен и второй путь, связанный с выделением ядерной энергии в процессах синтеза легких ядер из более легких, главным образом - синтеза гелия из изотопов водорода. К 1940 году стало ясно, что именно эти процессы происходят в звездах и являются источниками их энергии. Стало ясно и то, что для возникновения такой реакции нужна огромная начальная температура, поэтому реакция синтеза и была названа «термоядерной».

Вначале казалось, что получить в земных условиях такую температуру невозможно. Ведь что такое температура? Температура - это мера средней кинетической энергии частиц, когда их огромное число находится в хаотическом движении. Частицы непрерывно сталкиваются друг с другом, теряя и приобретая энергию. Всегда есть набор самых различных скоростей. Но при этом обязательно существует вероятностное распределение кинетической энергии частиц. Эта вероятность максимальна в области некоторой средней кинетической энергии $E$. В термодинамических расчетах используют понятие абсолютной температуры $T$, которое и есть эта средняя кинетическая энергия, только выраженная не в джоулях, а в кельвинах: $T=\alpha E$, где $\alpha=0,5 \cdot 10^{23} \mathrm{~K} /$ Дж .

Понимание того, что для начала реакции синтеза необходима огромная начальная температура, пришло благодаря выяснению строения атомного ядра и природы 
сил, действующих между нуклонами протонами и нейтронами. В атомном ядре действуют электрические силы отталкивания между протонами (кулоновские силы) и особые силы притяжения между нуклонами, получившие название ядерных сил. В современной физике соответствующие ядерным силам взаимодействия предпочитают называть сильными взаимодействиями. Они не имеют отношения к электрическому заряду частиц. Сильным взаимодействием обладают объекты, наделенные особым свойством - барионным зарядом. Он одинаков и для протонов, и для нейтронов и считается для них равным единице. Тем самым, суммарный барионный заряд ядра равен числу нуклонов в нем. Именно эта величина указывается в ядерных реакциях вверху перед символом элемента. Закон сохранения барионного заряда (числа ядерных частиц) наряду с законом сохранения электрического заряда определяют результат ядерной реакции.

Очень важной особенностью сильных взаимодействий является их близкодействие. На расстояниях, меньших $10^{-15}$ м, они проявляют себя как силы притяжения, примерно в 100 раз большие по величине, чем силы электрического отталкивания на таком расстоянии. Вот почему в ядрах необходимы нейтроны, и общие силы притяжения нуклонов уравновешивают электрическое отталкивание протонов.

Два ядра, которым удалось преодолеть их взаимное отталкивание (преодолеть кулоновский барьер) и сблизиться на расстояние $10^{-15}$ м, попадают в поле действия ядерных сил притяжения, устремляются друг к другу, сливаясь в одно целое. Образовавшийся комплекс сложен, это не просто несколько слипшихся шариков, а капля первозданного вещества Вселенной - кварко-глюоновой плазмы.

Образовавшиеся в результате слияния объекты, например ядро атома гелия и нейтрон, обладают суммарной кинетической энергией большей, чем та энергия, которая была затрачена на преодоление кулоновского барьера. Налицо - выигрыш энергии. Никакого нарушения законов сохранения при этом нет, поскольку масса

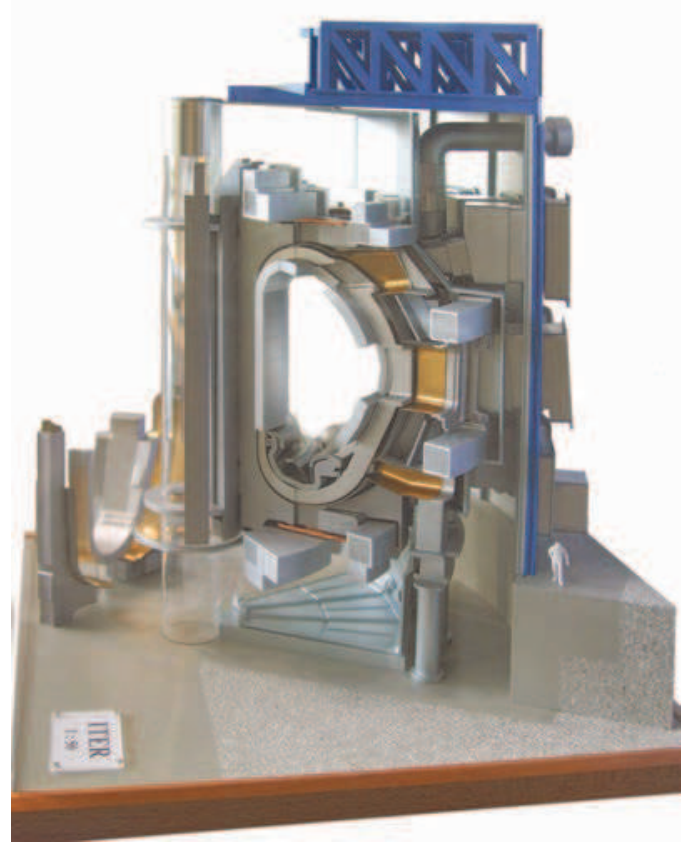

Макет термоядерного реактора (сечение)

покоя ядра гелия и нейтрона в сумме меньше, чем сумма масс ядер двух первоначальных изотопов водорода.

Какую же среднюю кинетическую энергию нужно придать ядрам изотопов водорода для того, чтобы они смогли преодолеть кулоновский барьер? Простой расчет - приравнивание потенциальной энергии электрического отталкивания начальной средней кинетической энергии частиц дает температуру порядка $10^{9} \mathrm{~K}$. Тот факт, что при этом некоторая часть частиц имеет кинетическую энергию значительно большую, чем средняя, и наличие квантового туннельного эффекта делают возможным сближение водородных ядер при более низкой температуре - «всего лишь» при 20 миллионах градусов.

Казалось, что на Земле создать такую температуру нельзя. Но все изменилось ранним утром 16 июля 1945 года, когда в США на полигоне Аламогордо в штате Нью-Мексико состоялось испытание первого ядерного (уранового) взрывного устройства. Вспыхнувший на мгновение ослепительный свет был «ярче тысячи Солнц», по образному выражению Роберта Оппен- 
геймера - американского физика, одного из создателей американского ядерного оружия. Спектральные измерения подтвердили предсказания теоретиков, что в момент взрыва бомбы температура будет порядка 20 миллионов градусов.

Почти одновременно в странах, где создавалось ядерное оружие (США, СССР и Великобритания), возникли проекты водородной бомбы - резервуара с изотопом водорода, внутри которого находилась урановая или плутониевая бомба. Вначале такие устройства были столь громоздкими, что их нельзя было использовать как бомбы. Но 22 ноября 1955 года водородная бомба с тротиловым эквивалентом 1,6 мегатонн была сброшена с самолета и взорвалась на высоте 1000 м над Семипалатинским ядерным полигоном в СССР. Вскоре аналогичные бомбы были сделаны и в США. И началась огромная по своим масштабам и страшная по своим возможным последствиям гонка вооружений между СССР и США. Кульминацией этой гонки стало испытание 30 октября 1961 года, когда на Новоземельском полигоне в СССР была взорвана «царь-бомба» с тротиловым эквивалентом 58 мегатонн.

\section{Управляемый синтез}

Практически одновременно с созданием водородной бомбы встала задача осуществления на Земле контролируемого, «при-

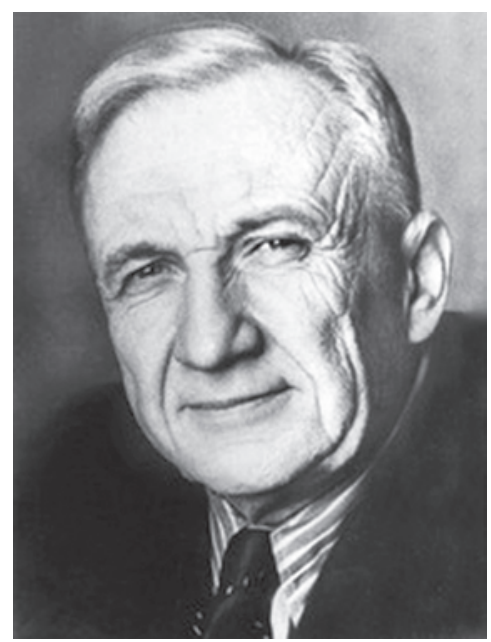

Игорь Евгеньевич Тамм

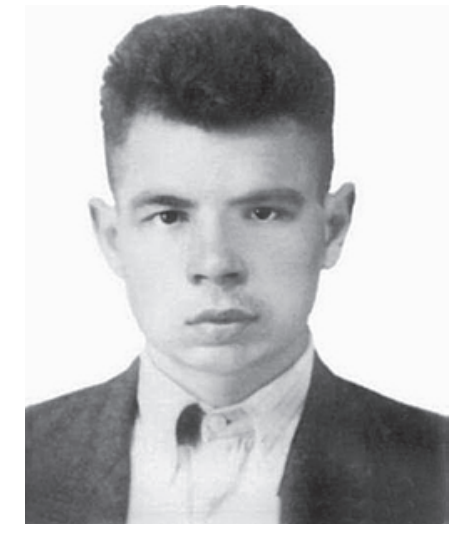

Олег Лаврентьев

рученного» процесса термоядерного синтеза без ядерного взрыва. Был выдвинут ряд идей создания сверхвысокой начальной температуры - использование концентрации многих лазерных лучей или электронных пучков. Одно время даже обсуждалась идея «холодного» термоядерного синтеза. Но наиболее серьезные исследования были связаны с возможностью создания сверхвысокой температуры с помощью мощного электрического разряда в водородной плазме.

Одна из первых идей была выдвинута в 1950 году в СССР военнослужащим, сержантом Олегом Лаврентьевым (19262011). Он не имел в это время даже законченного среднего образования, но его мечтой было стать физиком. На свои скудные сержантские средства он выписывал научные и научно-популярные журналы и покупал учебники по физике. Лаврентьев послал в адрес правительства и Академии наук письма с изложением сво-

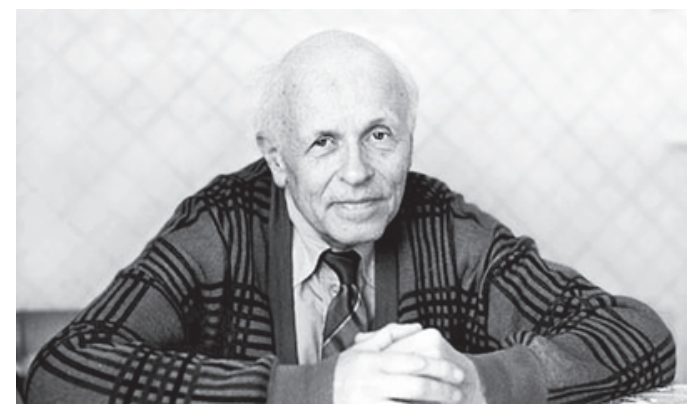

Андрей Дмитриевич Сахаров 


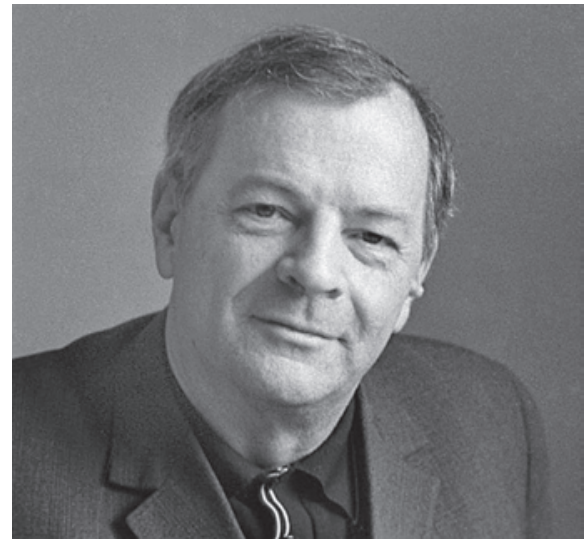

Лев Андреевич Арцимович

ей идеи получения термоядерной энергии. Эта идея заключалась в создании кругового электрического разряда в водороде, термоизоляция которого обеспечивалась бы электрическими силами отталкивания. Письма О.Лаврентьева были переданы в организации, занимавшиеся ядерными взрывами, и в конце концов попали к И.Е.Тамму и А.Д.Сахарову, которые в это время работали над созданием водородной бомбы. Они организовали демобилизацию О.Лаврентьева и его приезд в Москву, получение им среднего образования и поступление на физический факультет МГУ. Но сама идея Лавренть-

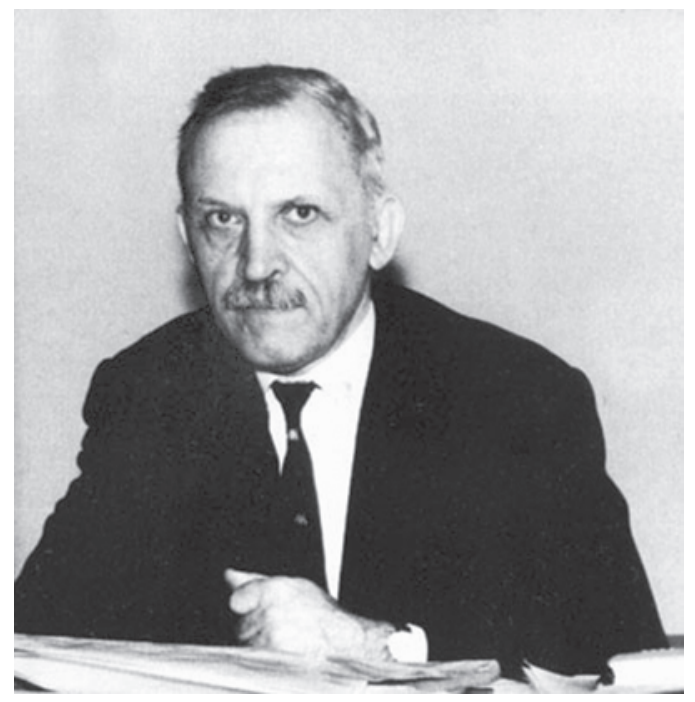

Игорь Николаевич Головин ева оказалась несостоятельной. Электрические поля не могли обеспечить устойчивое состояние кругового разряда. Лаврентьев и сам убедился в этом. Впоследствии, получив физическое образование, он работал в научных институтах, занимаясь ядерной физикой.

Тамм и Сахаров использовали рациональное зерно лаврентьевской идеи. В водородной плазме электрический ток действительно должен быть кольцевым, а сама плазма должна представлять собой тор (баранку). Но удерживать круговой ток в пространстве могло только магнитное поле особой конфигурации - линии индукции этого поля должны как бы обвивать плазменный тор. Ученые назвали такое поле тороидальным. Воплощение в жизнь этой идеи было связано с решением многих научных и инженерных задач. И в уже далеком 1951 году в созданном главным научным руководителем урановой проблемы в СССР И.В.Курчатовым секретном научном институте, называвшемся тогда Лаборатория №2 АН СССР или Лаборатория измерительных приборов, а попросту ЛИПАН или «двойка», появилось подразделение, которое начало воплощать в жизнь идею Тамма и Сахарова. Сегодня «двойка» превратилась в огромный Национальный исследовательский центр «Курчатовский институт», а подразделение, в котором начались работы по термояду, стало проектным центром ИТЭР, входящим в национальное агентство России по ИТЭР и в госкорпорацию «Росатом».

В 1951 году руководителями работ по осуществлению лабораторного термоядерного синтеза стали сотрудники И.В.Курчатова Л.А.Арцимович и И.Н.Головин один из главных координаторов «мозгового штурма» проблемы. С 1973 года руководителем работы стал Б.Б.Кадомцев, а с 1975 года - Е.П.Велихов.

\section{Токамак}

Для создаваемого устройства И.Н.Головин придумал название - токамак (TOроидальная КАмера с МАгнитными Катушками). Токамак-1 (Т-1) и Токамак-2 (Т-2) 
оказались неудачными - плазма разрушалась очень быстро. Наконец, в 1968 году на Т-3 был достигнут некоторый успех плазма с температурой 10 миллионов градусов просуществовала почти секунду. При этом были зафиксированы нейтроны продукты термоядерной реакции синтеза. Успех был повторен английскими физиками на их аналогичном устройстве. В мире начался настоящий бум сооружения подобных устройств - к 1986 году их общее число достигло 300. Этому способствовало полное рассекречивание работ по мирному использованию термоядерной энергии, которые велись в СССР.

В 1956 году И.В.Курчатов на конференции физиков-ядерщиков в английском ядерном центре Харуэлл сделал доклад, в котором рассказал об идее токамака и ее осуществлении в СССР. А в это время еще существовала во всех странах полная секретность работ по ядерной энергетике (о запуске в СССР ядерной электростанции в 1954 году было объявлено, но детали ее конструкции оставались строго секретными). Поэтому доклад Курчатова стал сенсацией. Мировое сообщество физиковядерщиков было поражено успехами советской физики и размахом работ по термоядерному синтезу. Сам термин «токамак» стал международным словом, не требующим перевода (несколько ранее так было со словом «спутник»).

В разных проектах использовались различные термоядерные реакции. Вот только некоторые из них (с указанием кинетической энергии продуктов реакции):

$$
\begin{gathered}
{ }^{2} \mathrm{H}+{ }^{2} \mathrm{H} \rightarrow{ }^{1} \mathrm{H}+{ }^{3} \mathrm{H}+4,0 \mathrm{Mэ} \mathrm{B}, \\
{ }^{2} \mathrm{H}+{ }^{2} \mathrm{H} \rightarrow{ }^{3} \mathrm{He}+{ }^{1} n+3,3 \mathrm{MэB}, \\
{ }^{2} \mathrm{H}+{ }^{3} \mathrm{H} \rightarrow{ }^{4} \mathrm{He}+{ }^{1} n+17,6 \mathrm{MэВ,} \\
{ }^{3} \mathrm{He}+{ }^{3} \mathrm{He} \rightarrow{ }^{4} \mathrm{He}+2{ }^{1} p+12,8 \mathrm{MэB}, \\
{ }^{2} \mathrm{H}+{ }^{3} \mathrm{He} \rightarrow{ }^{1} p+{ }^{4} \mathrm{He}+18,5 \mathrm{MэВ,} \\
{ }^{2} \mathrm{H}+{ }^{7} \mathrm{Li} \rightarrow 2{ }^{4} \mathrm{He}+{ }^{1} p+16,9 \text { МэВ. }
\end{gathered}
$$

Внутри звезд, где кроме водорода, гелия и лития присутствуют и ядра других легких элементов, возможны и иные ядерные реакции синтеза. Но основное энерговыделение определяется превращением водорода в гелий. Кинетическая энергия про- дуктов этих реакций синтеза в расчете на одну частицу оказалась в несколько раз больше, чем в реакциях деления тяжелых ядер.

Токамаки все больше увеличивались в размерах, создавались все более сильные магнитные поля, возрастала сила тока в плазме. При токах в тысячи ампер воздействующие на них магнитные поля должны иметь индукцию не менее 10 тесла - это в сотни тысяч раз больше магнитного поля Земли и в тысячи раз больше магнитных полей в электромагнитах подъемных кранах. Существование магнитного поля в катушке электромагнита определяется током в его обмотке. Для создания магнитных полей в десятки тесла сила тока в обмотке должна составлять десятки тысяч ампер. А это возможно только тогда, когда обмотки не будут иметь электрического сопротивления, т.е. будут сделаны из сверхпроводящего материала, и их температура не будет превышать 4 кельвинов. Единственным охладителем до таких температур может быть только жидкий гелий.

Технология создания сверхсильных магнитных полей создавалась для различных целей - для ускорителей заряженных частиц, для медицинских томографов. Но в этих случаях магнитное поле имело обычную соленоидальную форму. А в токомаке создание необычного тороидального поля требовало и необычных сердечников, и необычных их обмоток. Важнейшим воп-

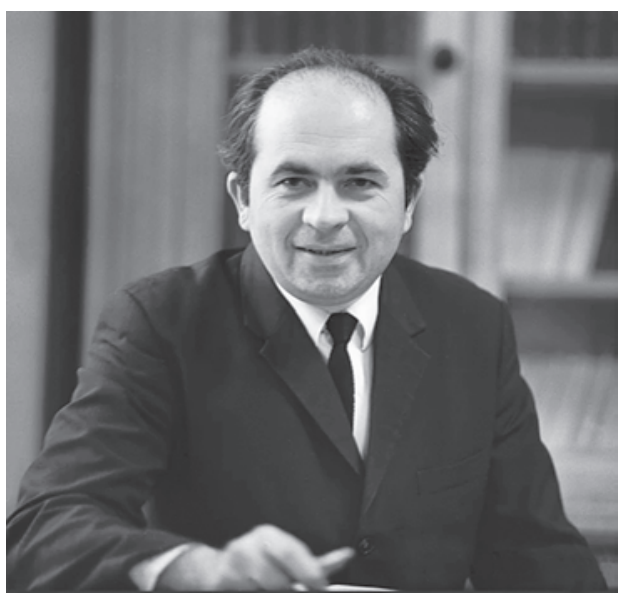

Борис Борисович Кадомцев 


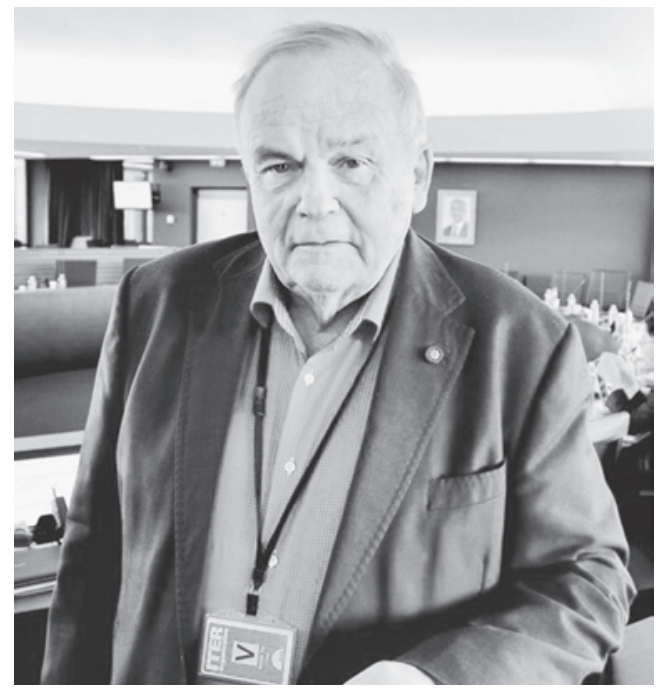

Евгений Павлович Велихов

росом становилась и защита внутренних стенок реакционной камеры от случайных выбросов плазмы с ее многомиллионной температурой, и защита этих стенок от разрушающего действия быстрых нейтронов, и десятки других трудностей, которые нужно было преодолевать. Мечта о 5-10 годах для решения проблемы «приручения» термоядерной реакции так и осталась мечтой.

В 1985 году были построены Токамак-15 и Токамак-16. Это были совместные разработки СССР-Китай и СССР-Япония, поскольку в Советском Союзе уже не было возможности затратить на эти работы миллионы долларов. Зато научными руководителями проектов были российские ученые - академики Б.Б.Кадомцев и Е.П.Велихов (Е.П. даже был награжден японским «Орденом восходящего солнца»). Длительность устойчивого состояния плазмы в этих реакторах уже превышала секунду. Но главное, стало ясно, что для длительного устойчивого состояния плазмы необходимы реакторы значительно больших размеров - примерно в 10 раз больших, чем Токамак-16. Стоимость сооружения такого реактора оценивалась уже в несколько миллиардов долларов. И ни одна страна в мире (включая и США) не могла себе позволить такой научный эксперимент. Тем более, что предполагае- мый реактор мог и не дать ожидаемого результата.

\section{Будущее мировой энергетики}

В то же время, к концу двадцатого столетия стало отчетливо ясно, что человечество стоит перед угрозой всемирного энергетического голода. Тогда, двадцать лет назад, $80 \%$ мировой электроэнергии производилось на тепловых электростанциях, использующих в качестве источника энергии каменный уголь и природный газ, $15 \%$ приходилось на гидроэнергию, 10\% на ядерные (урановые) электростанции. Энергия солнечного излучения, ветра, морских приливов и тепла земных недр составляла в общем энергетическом балансе лишь сотые доли процента.

Работы ряда международных организаций позволили оценить мировые запасы природных источников электроэнергии и темпы нарастания ее потребления. По самым оптимистическим прогнозам, природного газа должно хватить на 100 лет, каменного угля - на 300 лет, урана - на 500 лет. Значительно расширить производство гидроэнергии не представляется возможным по экологическим соображениям. Мощные гидростанции требуют создания огромных водохранилищ, а это может нанести непоправимый вред природе. Так, например, при постройке крупнейшей в мире гидростанции «Три ущелья» на реке Янцзы (мощностью 22,5 ГВт) созданное искусственное озеро площадью в 630 км $^{2}$ потребовало переселения трех миллионов человек. А в несколько раз меньшие по мощности российские гидростанции Братская и Усть-Илимская «снабжены» водохранилищами площадью 5400 км $^{2}$ и 1830 км $^{2}$. Это уже не озера, а целые моря.

Мы специально ничего не говорим о нефти, запасы которой, как известно, наиболее ограничены (максимум на 60-80 лет). В получении электроэнергии сама нефть не играет заметной роли. Она используется для транспорта - авиационного, автомобильного, водного и железнодорожного. Часть транспорта, конечно, можно будет перевести на электри- 
ческие двигатели, как уже это сделано для железнодорожного транспорта. Но, во-первых, это даст еще большую нагрузку на сжигание газа и каменного угля и, во-вторых, довольно трудно представить авиацию на «электрической тяге». А главное, прекратить использование нефти в качестве топлива придется довольно скоро, ведь нефть - невосполнимый источник многих химических технологий. Перефразируя Д.И.Менделеева, скоро можно будет сказать, что дешевле сжигать в автомобилях ассигнации, чем бензин.

Что произошло в мировой энергетике за прошедшие 20 лет? Главное изменение это значительное увеличение доли используемого в качестве источника энергии природного газа. Она увеличилась с 5 до $15 \%$. Соответственно, доля каменного угля уменьшилась до 50\%. Гидроэнергия обеспечивает $20 \%$, а ядерная энергия - $12 \%$. По-прежнему крайне незначительна роль в энергетическом балансе энергии солнечного излучения и ветровой энергии. Увеличение доли природного газа в знергобалансе безусловно снижает экологический вред от сжигания каменного угля, в продуктах горения которого содержится целый ряд вредных газов и микрочастиц тяжелых металлов. Улавливание этих примесей перед выбросом газов в атмосферу обходится очень дорого. Это смогли себе позволить США, где сжигание каменного угля дает $60 \%$ энергии. А вот экологическая обстановка в густонаселенных районах Китая катастрофически ухудшается. В этой стране, почти лишенной природного газа, 75\% электроэнергии производится за счет сжигания каменного угля. Россия в этом отношении - благополучная страна. Уже только 20\% электроэнергии производится на угольных электростанциях, а 55\% дает природный газ. Суммарная доля использования гидроэнергии и ядерной энергии примерно соответствует среднемировому показателю - 32\%.

\section{Атомная эра}

По использованию в качестве источника энергии урана в мире существует резкая дифференциация. Всего сейчас работает
191 ядерная электростанция с 451 ядерным реактором (еще 60 реакторов находятся в стадии строительства). Из этого числа 100 реакторов построены в США и дают этой стране 20\% электроэнергии. В России 36 реакторов дают почти пятую часть электроэнергии. Есть страны, в которых ядерная энергия - это треть энергии в ее общем балансе (Южная Корея, Финляндия). Имеются страны, где эта доля почти половина всей энергии (Словакия, Украина). А вот в Китае и Индии доля ядерной энергии в общем балансе меньше $5 \%$. Совсем не используется ядерная энергия в Австралии, в большинстве стран Южной и Центральной Америки и в многочисленных мелких государствах Океании. Опережает все страны по этому показателю Франция, в которой 58 ее ядерных реакторов производят $77 \%$ всей вырабатываемой в стране электроэнергии. Неслучайно статья в Википедии об экономике Франции начинается словами: «Франция - высокоразвитая страна, ядерная и космическая держава» .

Отчасти это объясняется тем обстоятельством, что во Франции еще в 30-е годы прошлого века начали развиваться работы по ядерной физике. Ирен и Фредерик Жолио-Кюри (как и Энрико Ферми в Италии) стали нобелевскими лауреатами за получение новых изотопов («меченых атомов»). Но они не поняли, что в их опытах наблюдалась также реакция деления урана. Об этом догадались немецкие радиохимики и физики О.Ган, Ф.Штрассманн, Л.Мейтнер. Началась атомная эра. Энрико Ферми продолжал работы с ураном уже в США. Он изобрел и построил ядерный реактор, где в ноябре 1942 года впервые в мире была осуществлена цепная ядерная реакция деления урана. Но целью создания первых реакторов было не выработка электроэнергии, а получение плутония, искусственного трансуранового элемента, способного, как и уран, к взрывному осуществлению реакции деления.

После окончания войны и ужасных августовских событий 1945 года в Хиросиме и Нагасаки интересы многих физиков-ядерщиков сосредоточились на мирном ис- 
пользовании энергии деления. Их вдохновлял и запуск в 1954 году первой в мире ядерной электростанции в СССР. В реакторостроении Франция вскоре стала мировым лидером. Возможно, в этом немалую роль сыграли и почти полное отсутствие во Франции секретности ядерных исследований, и большой интерес к этим исследованиям французского правительства. На юге Франции, в маленьком городке Кадараш в 60 километрах от Марселя был создан мощный научный центр ядерной физики.

И именно там, неподалеку от Кадараша, в 2006 году было намечено построить ИТЭР - международный термоядерный экспериментальный реактор. Огромную строительную площадку размером с 400 футбольных полей было решено создать в лесном массиве, поскольку вся безлесная сельскохозяйственная округа была арендована частными владельцами. Первое дерево было срублено 29 января 2007 года. Но перед этим несколько лет уточнялись научные предпосылки строительства реактора и почти пять лет разрабатывался технический проект сооружения. Много времени ушло и на организацию финансирования проекта и создание управляющих органов. Первоначально планировалось запустить реактор в 2022 году и затратить 5 миллиардов долларов. Но в 2012 году проект был пересмотрен, сроком окончания строительства был намечен 2025 год, а предполагаемая сумма затрат возросла до 20 миллиардов долларов. Сейчас пройдена половина дистанции, и панорама строительства поражает воображение.

Кто же затеял и осуществил проект этой грандиозной стройки, поистине «стройки XXI века»? Как возникла система финансирования и изготовления многочисленных узлов и агрегатов будущего реактора?

\section{История проекта ИТЭР}

Как уже было сказано, в 80-е годы прошлого столетия ученые разных стран, занимавшиеся проблемой «приручения» термоядерной энергии, пришли к единому мнению: необходима постройка экспериментальной установки такой мощности и таких размеров, что это недоступно от- дельной стране, и поэтому необходима международная кооперация.

Некоторый опыт международного научного содружества в Европе уже был. В 1954 году был создан ЦЕРН (русское произношение международной аббревиатуры CERN, от Conseil Européen pour la Recherche Nucléaire - Европейский совет по ядерным исследованиям). Сегодня это крупнейшая коллаборация по физике высоких энергий, в которой принимают участие ученые 20 стран. Только на постоянной работе в ЦЕРНе заняты 2500 человек. За прошедшие годы там сооружено несколько ускорителей, в том числе крупнейший в мире Большой адронный коллайдер (БАК). На них совершено 11 крупных открытий в физике элементарных частиц. ЦЕРН награжден Большой золотой медалью ЮНЕСКО. Не менее важно и то, что именно в ЦЕРНе родилась «всемирная паутина», вначале как компьютерная сеть для распространения научной информации. Но в 1993 году эта сеть была открыта для всех пользователей - так родился интернет.

Идея создания ЦЕРНа была высказана в 1949 году Луи де Бройлем в Лозанне (Швейцария) на европейской конференции по культуре. Идея была горячо поддержана физиками, а энергия и авторитет Нильса Бора помогли претворить ее в жизнь. В разгаре холодной войны советские физики не могли участвовать в создании и работе ЦЕРНа - почти все исследования в ядерной физике тогда были строго засекречены. Россия и сейчас не является страной-участницей этой организации. Но уже в строительстве БАКа и в его работе финансовый вклад России составил 5\%, а научный вклад - заметно больше.

Мечта физиков зажечь на Земле звездную реакцию синтеза совпала с крутым изменением политической обстановки в России в 1985 году. Генеральный секретарь ЦК КПСС М.С.Горбачев обозначил целью своей деятельности прекращение холодной войны («разрядку»), полное запрещение всех ядерных испытаний и начало решительного сокращения страшных арсеналов термоядерного оружия, накоп- 
ленного двумя мировыми державами. Российские руководители программы мирного использования термоядерной энергии академики Б.Б.Кадомцев и Е.П.Велихов в 1986 году встретились с М.С.Горбачевым и увлекли его своей идеей мирового сотрудничества в этой области. М.С.Горбачев понял важность проблемы и включил этот вопрос в программы своих встреч с лидерами ведущих стран мира. Е.П.Велихов стал его советником по этому вопросу и принимал участие в международных встречах. Решающую роль сыграла встреча М.С.Горбачева с президентом США Дональдом Рейганом в конце 1986 года в Рейкьявике (Исландия), на полдороге между Москвой и Вашингтоном. Рейган был незаурядным политиком. Бывший знаменитый киноактер, он был образованным человеком и имел хороших советников. В одном из интервью на журналистский вопрос о том, чем он руководствуется в своей внешней и внутренней политике, Рейган ответил: «Принципом дополнительности Нильса Бора». И разъяснил журналистам этот принцип, основанный на квантовом соотношении неопределенностей.

Неизвестно, поняли ли Рейгана журналисты, но одним из результатов встречи руководителей двух стран стало создание под эгидой МАГАТЭ (Международного агентства по атомной энергии) группы ученых, разрабатывающих возможность создания нового крупного научного международного содружества. Большое участие в этом принял и президент Франции Франсуа Миттеран. В 1987 году эта группа стала Международным консультативным комитетом проекта ИТЭР, а возглавил этот комитет академик Б.Б.Кадомцев.

Международный консультативный комитет подготовил заключение в Вашингтоне в июле 1992 года международного четырехстороннего соглашения о разработке инженерного проекта ИТЭР. Участниками этого соглашения были Россия, США, Япония и ЕС (Европейское содружество). Очень сложным вопросом было финансирование разработки проекта. Острой необходимостью стало создание полномочной международной организации по руковод-

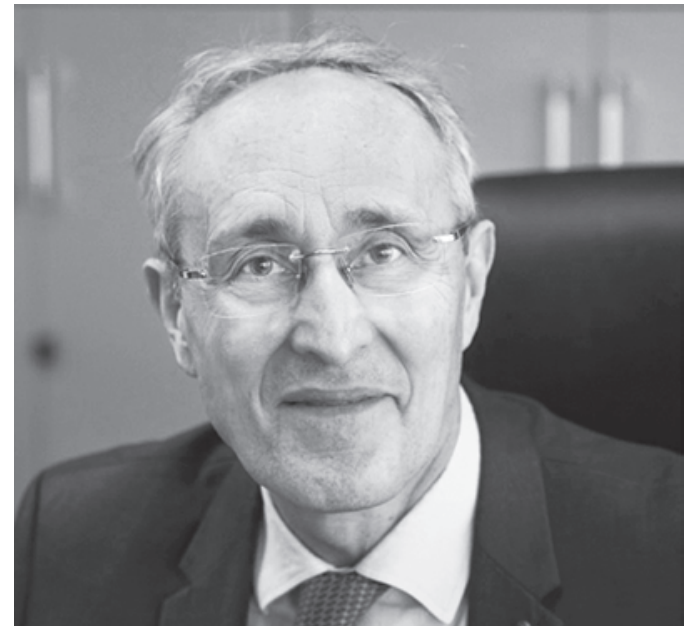

Бернард Биго

ству всей этой работой. Необходим был международный договор. Трудно переоценить участие Е.П.Велихова в подготовке этого договора. Его личные контакты со всеми ведущими физиками-реакторщиками, его бесспорный научный авторитет в этой области обеспечили успешное, хоть и не очень быстрое решение проблемы.

Наконец, в мае 2006 года в Брюсселе состоялось соглашение о создании Международной организации по реализации проекта, которая будет обладать правами юридического лица, способного заключать договоры с государствами и международными организациями. В июне 2006 года в Москве первые шесть стран-участниц этого соглашения определили место сооружения реактора. В сентябре 2006 года правительство России приняло решение поддержать это соглашение, тем самым Россия стала страной-участницей. В декабре этого года уже было заключено несколько десятков контрактов с конкретными исполнителями проекта.

Был создан управляющий орган - совет ИТЭР. Его генеральными директорами вначале были японские физики-реакторщики - ведь именно в Японии был создан самый продвинутый реактор Токамак-16. Российский ученый, академик Е.П.Велихов стал главным научным руководителем проекта. В 2015 году генеральным директором совета ИТЭР был избран 65-летний 
французский физик Бернард Биго, а 80летний Е.П.Велихов стал почетным консультантом совета, он и сейчас продолжает принимать активное участие в его работе. Во всех странах-участницах были созданы национальные агентства ИТЭР. В России такое агентство входит в государственную корпорацию «Росатом».

Одной из важнейших задач совета ИТЭР является определение плана работ и сметы строительства на каждый год и, что особенно важно, распределение между странамиучастницами работ по созданию отдельных узлов и агрегатов реактора. Полный расчетный объем финансирования составляет на 2018 год около 2 миллиардов евро. Он разделен на 11 частей, или паев. По одному паю имеют Россия, США, Китай, Южная Корея и Индия, 2 пая имеет Япония, Европейский Союз имеет 4 пая, которые уже сам распределяет по отдельным странам Европы (в общей сложности в проекте принимают участие 26 стран).

Участие этих стран заключается не только в финансировании работ по самому строительству реактора. Они финансируют также научные разработки, инженерные проекты и изготовление по этим проектам тех элементов конструкции, которые советом ИТЭР и национальными агентствами ИТЭР им поручено выполнить и доставить на строительную площадку.

Почему мы выделили отдельно вопрос доставки? Вот небольшой штрих, характеризующий грандиозные масштабы стройки. Отдельные детали и установки имеют массу в десятки и сотни тонн. Так, некоторые детали, изготовленные в России, имели массу по 50 тонн. Морем они доставлялись в немецкий порт Киль, а оттуда по автобанам на многотонных трейлерах - на юг Франции. Но были и будут «детали», имеющие массу по 300 тонн и более. Как их доставить? В 2017 году в Южной Корее были изготовлены газгольдеры для хранения охлажденного гелия. Масса каждого газгольдера 300 тонн, диаметр 6 метров, высота 30 метров. С Дальнего Востока они были доставлены морем во внутренний порт Средиземного моря около Канн и погружены на специальные платформы- трейлеры. Но чтобы выдерживать такую массу, трейлеру нужно иметь 354 колеса! По модернизированной 100-километровой дороге трейлеры со скоростью 5 километров в час передвигались в сопровождении конвоя по ночам, когда останавливалось все движение. Теперь эти газгольдеры, установленные огромными кранами, гордо красуются на предназначенных им по проекту местах. И краны, и платформытрейлеры были изготовлены во Франции специально для этой стройки.

На строительстве сейчас занято свыше 2000 инженеров, техников и рабочих, а в штабе стройки и в научном руководстве задействовано больше 400 сотрудников. Есть небольшой жилой поселок, общежития гостиничного типа, медицинские и детские учреждения. Предусмотрен транспорт для детей школьного возраста в город Кадараш. Общее число всех, кто занят в проекте ИТЭР в 26 странах мира, оценивается в 200000 человек. Невероятно трудно координировать работу этого грандиозного коллектива. Очень важно соблюдение сроков выполнения отдельных узлов для обеспечения непрерывности работы на стройке. Нынешний генеральный директор совета ИТЭР Бернард Биго регулярно посещает все страны-участницы, наблюдая и контролируя работы в них.

В России национальное агентство по ИТЭР привлекло к работе 10 научноисследовательских и конструкторских центров, 5 крупных заводов с общим числом работников порядка 20000 человек. Генеральный директор совета ИТЭР на недавном заседании назвал российское участие в проекте самым надежным и по срокам, и по качеству выполнения работ.

Чтобы составить представление о том, что же там, во Франции, строится, нужно немного подробнее остановиться на принципах работы и конструкции этого термоядерного реактора. Но об этом - в следующий раз. 